JOURNAL OF SECURITY AND SUSTAINABILITY ISSUES ISSN 2029-7017 print/ISSN 2029-7025 online 2020 June Volume 9 Number 4 https://doi.org/10.9770/jssi.2020.9.4(28)

\title{
CHINA: INSIGHTS INTO PECULIARITIES OF DEVELOPMENT
}

\author{
Natalya V. Osokina ${ }^{1}$, Mariana Petrova ${ }^{2}$, Natalia V. Kudrevatykh ${ }^{3}$, Evgeny E. Zhernov ${ }^{4}$ \\ ${ }^{1,3,4}$ T.F. Gorbachev Kuzbass State Technical University, 28 Vesennyaya Str., Kemerovo, 650000, Russian Federation \\ ${ }^{2}$ St. Cyril and St. Methodius University of Veliko Tarnovo, 2 T. Tarnovski Str., Veliko Tarnovo, 5000, Bulgaria \\ E-mails: ${ }^{1}$ onv.eti@kuzstu.ru; ${ }^{2} m . p e t r o v a @ t s . u n i-v t . b g$ (corresponding author); \\ ${ }^{3} k n v . f k @ k u z s t u . r u ;{ }^{4} z h e e . e t i @ k u z s t u . r u$
}

Received 18 November 2019; accepted 4 April 2020; published 30 June 2020

\begin{abstract}
The subject of the study is economic relations between USA and China. The aim of the study is to characterize the dynamics of the world-system status of China in the XX-XXI centuries and the economic characteristics of its mode of production at present. The main idea of the article is to substantiate the untenability of considering the real state of the economic system of China as "socialism with Chinese characteristics". Currently, China is integrated into the world-system according to the Beijing Consensus model. The model of China is a specific Asian capitalism, in which a special mode of capital accumulation is formed - with a higher role of the state in the process of capital accumulation than in the fourth cycle of capitalist accumulation. Its world-system status can be characterized as a strong semi-periphery, which entered the competition for hegemony in the next system cycle of capitalist accumulation. If the motion path leads China to the goal, it will be for the first time a specific non-Western hegemony. This research result allows determining the prospects for changing relations in the world economy as a result of the completion of the fourth system cycle of capitalist accumulation.
\end{abstract}

Keywords: China; the USA; world-system; economic leadership; capital accumulation

Reference to this paper should be made as follows: Osokina, N., Petrova, M., Kudrevatykh, N., Zhernov, E. 2020. China: insights into peculiarities of development, Journal of Security and Sustainability Issues 9(4), 1459-1469.

https://doi.org/10.9770/jssi.2020.9.4(28)

JEL Classifications: F01, F60, P51

\section{Introduction}

Currently, the global economy has seen a downward trend in economic growth. According to the Organisation for Economic Co-operation and Development, "global economic growth will slow to $2.9 \%$ in 2019 and to $3 \%$ in $2020^{1}$, which is the lowest annual growth rate after the 2008 financial crisis. Economic growth prospects were revised downwards for almost all G20 countries" (World Economy Review - September 2019, 2019). The growth rate of large economies has a significant impact on the dynamics of world GDP: the USA, China, Japan, etc. This dynamics also directly depends on the relationship between the United States and China, the nature of which is determined by the approaching completion of the fourth system cycle of capital accumulation (Arrighi, 2010), in which the process of transition to a new technological order and the struggle for a future new leadership in the world-system are intertwined. These relationships increase trade tension and worsen the investment climate. According to experts unrelated state activities may significantly hamper the innovation performance (Naama, 2001; Naama, 2011; Musaripov et al., 2019).

1 Without taking into account the impact of the coronavirus pandemic. 
Economic relations between the USA and China are on the agenda that defines the 21 st century. It is very relevant to clarify the development path in the world-system coordinates of one of the subjects of this relationship - the People's Republic of China (hereinafter the PRC). Economic strategy should be based on the reality of the economic characteristics of both China itself and the essence of relations between the participants in the world economy, which may emerge as a result of the completion of the fourth system cycle of capitalist accumulation. This determines the theoretical and practical significance of this study.

The central category in world-system analysis is the capitalist world-economy. The hegemonic state derives the largest share of world-system rent from the world economy. It is a country that plays a major role in the functioning of the specific accumulation mode characteristic of each cycle and has a quasi-monopoly on leadership and control in the interstate system. It has advantages in all three main economic fields: agro-industrial, commercial and financial, as well as global military force.

At present, there is an intensification of the US-China leadership competition (Nuruzzaman, 2016; Sun, 2019) in the current system cycle. The dynamic development of the Chinese economy puts the following questions on the research agenda. What are the prospects for this development? What quality of relations in the global economy will it lead to?

\section{Dynamics of Economic Development of China in the XX Century}

The Celestial Empire entered the 20th century as a periphery. By the middle of the century, China proclaimed building socialism, which was carried out under the patronage of the USSR, taking into account the programs of Soviet economic transformations adapted to Chinese conditions. What are the real successes in building socialism in China?

The basis of the ideology of the PRC was Maoism, which developed under the influence of Marxism-Leninism and traditional Confucian ideology. According to the theory of the unique stability of Chinese traditions (B. Schwartz, R. Solomon), Communism best represented the Chinese tradition and, in fact, was a revival of traditional authoritarian China in new forms (Lukin, 2011). L. Pye wrote: "the Communists again gave the Chinese a political system concentrated around a bureaucratic hierarchy, this time in the form of a communist party, and again integrated with an all-pervasive ideology - Marxism and Maoism ... It is important that the imperial bureaucracy and the communist party in procedural practice, like Confucianism and Maoism in the ideological content, clearly emphasized issues of power and order" (Pye, 1992).

After the death of Mao in 1976, the reforms of Deng Xiaoping began, which were based on the implementation of the "policy of four modernizations": in industry, army, agriculture and science (Deng Xiaoping and His Economic Reforms, 2016). His visit to the United States in 1979 marked China's intention to return to the world capitalist scene. "In other words... Deng Xiaoping came to "sell" a huge reserve of Chinese labor at a low price to transnational US corporations; in response the latter had to introduce technologies into China's industry" (Estachy, 2015). In the course of the aforementioned transaction, the United States sharply increased the scale of world-system rent drawing, associated with obtaining a huge amount of goods at a low price, as well as a massive influx of Chinese capital (due to the surplus of the Chinese trade balance) in US Treasury bonds.

It should be emphasized that until the end of the $80 \mathrm{~s}$. XX century, the private sector as a separate form of production was absent in China. Since the 80s XX century in China, the process of economic liberalization was carried out, manifested in the attraction of foreign capital and the expansion of private capitalist production. The corporatization began to spread; the law on corporations was adopted, which implied the transformation of most of the state-owned companies into corporations. In the 21 st century, the development of a system of private banks began, which is an innovation for the Chinese economic system, since for a long time it relied on large state-owned banks. At present, the public sector in China is already smaller than the private, with the exception of large processing enterprises, which have asserted themselves on the world market and have established ties with foreign companies and suppliers of raw materials. 
In 1978, when Deng Xiaoping's economic reforms were just beginning, the public sector accounted for $78 \%$ of the gross domestic product, and by 2008 , non-state enterprises produced $72 \%$ of GDP, and state-owned $28 \%$ (Semin, 2011). Gradually, private capital is being expanded in sectors that are mainly occupied by state-owned companies, including the banking sector, mining, transport, telecommunications, construction, medicine, education, and utilities. In 2016, every 13th of the eight millions of Chinese graduates opened own business (Kononovich, 2017).

In the 1990s, a Shanghai group came to power in the PRC, which rid the project of socialist China of ideological bias with the term "socialist market economy". Is it correct to consider the social system of modern China "socialism with Chinese characteristics" in terms of ideology and economics? Opinions on this point are controversial. "The Chinese themselves call their formation socialist, while developing private enterprise and growing capitalist corporations" (Kononovich, 2017). S. Glazyev attributes to China the formation of a new world economic structure, which he called integral. This structure is characterized by a combination of elements of the communist and capitalist systems, and, according to the researcher, the former prevails. The institutional systems of the countries which have such a structure "protect public interests and subordinate to them the regulation of capital reproduction processes", ensuring "the priority of public interests over private ones" (Glaziev, 2016). In all official speeches and reports of the highest party leaders, the term "socialist market economy" is state capitalism, a turn to which was carried out by Deng Xiaoping, and then the Shanghai group brought it to its logical conclusion.

Chinese labor laws more or less comply with central European standards, but are systematically ignored. Experts note the rather difficult working and living conditions of most workers in China. The country has an impressive "reserve army of labor", which has a negative impact on wages. In 2007, "surplus labor" in rural areas ranged from 150 to 170 million people.

In the 50s of the last century, the hukou system (Colas, Ge, 2019) - a strict registration system in which the distribution of food and other resources was tied directly to the place of registration and restricting the mobility of most Chinese - was introduced in China. Only a small number of Chinese were allowed to live in cities. It gave rise to a system of internal migration and the workers "Minggong" or "Mingun", i.e. "peasants-at-work" with a temporary residence permit in the city, usually for a period of one year. They do not have the same rights and opportunities as the owners of a permanent city residence permit; they cannot apply to many social services of the city. They account for $57.5 \%$ of the workforce in industry, $37.0 \%$ in the service sector, and most of the 20 million domestic workers. About half of the Minggong are women. Their most significant problems include low salaries and their delays, 10-12 hours a day (many still have overtime), neglect of work safety and accident rate, lack of social protection, poor living conditions, isolation and discrimination. The Minggongs have been struggling a lot, but it is very complicated by the joint opposition of company leaders and local administrations. China has a system of state trade unions, but it often does not resolve workers' disputes to the extent that they would like to.

\section{PRC's Entry in Competition For Hegemony in the World System}

At present, China is increasing its economic indicators, claiming to be a leader of the world system. In fact, it has already won an advantage in the sphere of production and trade. China produces the world's largest industrial output, exceeding the United States by more than 2 times and reaching leading positions in many traditional manufacturing industries. China has the largest turnover in the world and occupies a fairly high place in the ranking of Global Innovation Index. China also appears to undertake economic leadership in its capital export (Tvaronavičiene, 2019). A number of key economic indicators of the USA and China are presented in the table 1 . 
Table 1. The USA and China in the global economy in 2018

\begin{tabular}{|c|c|c|c|}
\hline & The USA & China & World total \\
\hline Nominal GDP, billion USD & 20412 & 14092 & 84740 \\
\hline World GDP share and ranking & $0,24(1)$ & $0,16(2)$ & 1 \\
\hline Population, million people & 329 & 1433 & 7713 \\
\hline GDP per capita, USD & 62042 & 9833 & 10986 \\
\hline Industrial production volume, billion USD and world ranking & $3601(2)$ & $8414(1)$ & - \\
\hline Turnover, billion USD & 3956 & 4105 & 35754 \\
\hline Turnover, $\%$ of world & 11,1 & 11,5 & 100 \\
\hline HDI ranking and points & $13(0,924)$ & $86(0,752)$ & 0,728 \\
\hline Gini coefficient & 37,8 & 51,0 & - \\
\hline Global Innovation Index, ranking & 6 & 17 & - \\
\hline
\end{tabular}

Source: compiled by the authors according to (Global GDP of the World: 1980-2018, 2019), (Global Innovation Index 2018, 2018), (Human Development Indices and Indicators, 2018), (Shuvalov, 2020), (The Leading Nations in World Trade, 2018), (World Economies Ranking 2019, 2019), (World Population Prospects 2019, 2019)

China's development trends are such that it is actively improving its position in value chains with the goal of turning from a large trading power into a powerful one. China is increasingly consolidating its position in world trade in goods and services. According to the data of the General Administration of Customs, Chinese exports grew by $9.9 \%$ in 2018 , imports increases by $15.8 \%$, and the surplus in foreign trade reached $\$ 546.8$ billion (China's foreign trade, 2019). This is ensured by the increasing level of industrial development that allows offering the world market new competitive products with high added value (see Table 2 ). Over $90 \%$ of the goods in the export structure are finished products.

Table 2. China's export structure in 2018

\begin{tabular}{|c|c|c|c|}
\hline No & Commodity line & $\begin{array}{l}\text { Commodity line } \\
\text { cost, million } \\
\text { dollars }\end{array}$ & $\begin{array}{l}\text { In total } \\
\text { export, } \\
\%\end{array}$ \\
\hline 1 & $\begin{array}{l}\text { Transmitting equipment for broadcasting or television, whether or not incorporating receiving, sound } \\
\text { recording or reproducing equipment; television cameras, digital cameras and camcorders }\end{array}$ & 197033 & 7.89 \\
\hline 2 & $\begin{array}{l}\text { Computing machines and their blocks; magnetic or optical readers, machines for transferring data to } \\
\text { information carriers in encoded form, and machines for processing such information }\end{array}$ & 173424 & 6.95 \\
\hline 3 & Electronic integrated circuits & 85969 & 3.44 \\
\hline 4 & $\begin{array}{l}\text { Telephones, including telephones for cellular communication networks or other wireless } \\
\text { communication networks; other equipment for transmitting or receiving voice, images or other data, } \\
\text { including equipment for communication in a wired or wireless data network }\end{array}$ & 54070 & 2.16 \\
\hline 5 & $\begin{array}{l}\text { Parts and accessories (except for cases, covers for transportation and similar products) intended } \\
\text { exclusively or mainly for automobiles }\end{array}$ & 45570 & 1.82 \\
\hline 6 & $\begin{array}{l}\text { Petroleum and petroleum products derived from bituminous rocks, other than crude; products containing } \\
70 \mathrm{wt} \% \text { or more of petroleum or petroleum products derived from bituminous rocks; waste oil }\end{array}$ & 35752 & 1.43 \\
\hline 7 & Parts and accessories of motor vehicles & 34850 & 1.39 \\
\hline 8 & $\begin{array}{l}\text { Lamps and lighting equipment, including searchlights, narrow-beam lamps, headlights and parts } \\
\text { thereof; light signs, light plates with a name or title, or address and similar products having a constant } \\
\text { source of lighting }\end{array}$ & 30586 & 1.22 \\
\hline 9 & $\begin{array}{l}\text { Diodes, transistors and similar semiconductor devices; photosensitive semiconductor devices, } \\
\text { including photovoltaic cells, assembled or not assembled into modules, mounted or not mounted in } \\
\text { panels; light emitting diodes; piezoelectric sensors }\end{array}$ & 29055 & 1.16 \\
\hline 10 & Other furniture and parts thereof & 28090 & 1.12 \\
\hline 11 & $\begin{array}{l}\text { Traveling bags, suitcases, handbags, cases for business papers, briefcases, school bags, cases for } \\
\text { glasses, binoculars, cameras, musical instruments, guns, holsters and similar products; travel bags, } \\
\text { thermos bags for food }\end{array}$ & 27401 & 1.10 \\
\hline 12 & Electric transformers, static electrical converters (e.g. rectifiers), inductors and chokes & 26695 & 1.07 \\
\hline 13 & Other commodity lines occupying less than $1.5 \%$ & 1721505 & 69.25 \\
\hline
\end{tabular}


The range of export goods totals more than 50 thousand items of goods and services and is constantly expanding. Traditionally, China is a leading exporter of textiles, toys, clothes, shoes, etc., however, the country has taken a leading position in the world in the export of electronics, office equipment, automobiles and other hightech products over the past decade. Machinery accounts for more than $57 \%$ of exports, high-tech products more than $27 \%$. Seven types of labor-intensive consumer goods (textiles, etc.) account for no more than $20 \%$ of exports. Thus, the commodity structure of Chinese exports becomes more similar to that of highly developed industrial countries. China has achieved great success in exporting services - construction, telecommunications, information and computer (Liu, Chernetsova, 2018).

The main goods of Chinese imports in 2018 were machinery and equipment, electronics, electronic circuits, mineral and fuel resources (see Table 3).

Table 3. China's import structure in 2018

\begin{tabular}{|c|l|c|c|}
\hline No & \multicolumn{1}{|c|}{ Commodity line } & $\begin{array}{c}\text { Commodity line } \\
\text { cost, million } \\
\text { dollars }\end{array}$ & $\begin{array}{c}\text { In total } \\
\text { import, } \\
\%\end{array}$ \\
\hline 1 & Electronic integrated circuits & 313222 & 14.60 \\
\hline 2 & Crude oil and crude oil products derived from bituminous minerals & 239222 & 11.2 \\
\hline 3 & Iron ores and concentrates, including calcined pyrite & 75011 & 3.51 \\
\hline 4 & Petroleum gases and other gaseous hydrocarbons & 50035 & 2.34 \\
\hline 5 & $\begin{array}{l}\text { Cars and other motor vehicles intended primarily for the transport of people (except } \\
\text { motorcycles), including utility vehicles and vans and racing cars }\end{array}$ & 49610 \\
\hline 6 & Gold (including platinum plated gold), unwrought or semi-wrought, or in powder form & 2.32 \\
\hline 7 & $\begin{array}{l}\text { Telephones, including telephones for cellular communication networks or other wireless } \\
\text { communication networks; other equipment for transmitting or receiving voice, images or other } \\
\text { data, including equipment for communication in a wired or wireless data network }\end{array}$ & 42506 \\
\hline 8 & Soybeans, whether or not crushed & 2.14 \\
\hline 9 & $\begin{array}{l}\text { Computing machines and their blocks; magnetic or optical readers, machines for transferring } \\
\text { data to information carriers in encoded form }\end{array}$ & 3379 \\
\hline 10 & Liquid crystal devices & 3376 & 1.99 \\
\hline 11 & Machines and mechanical devices with individual functions & 33772 & 1.58 \\
\hline 12 & Copper ores and concentrates & 32818 & 1.55 \\
\hline 13 & Other commodity lines occupying less than 1.5\% & 32728 & 1.55 \\
\hline
\end{tabular}

Source: compiled by the authors according to (China. Import, 2019)

A little bit more than 1/5 of China's total imports are raw materials: oil and oil products, gas, ores and concentrates, unwrought or semi-wrought gold. According to the World Atlas, the import of fuel and energy resources is $17.5 \%$ in 2018 , food imports is $6.3 \%$ (China. Data and statistics, 2020). The largest trading partners to import goods to China in 2018 were: South Korea with a share of $9.58 \%$ in the total value of the import of goods, Japan with a share of $8.44 \%$, the United States with a share of $7.3 \%$, Germany with a share of $4.97 \%$, Australia with a share of $4.92 \%$, Brazil with a share of $3.61 \%$, Vietnam with a share of $3 \%$, Malaysia with a share of $2.96 \%$ (China. Import and export, 2020). China imports planes, cars, semiconductor products, and agricultural products from the United States, mainly soy, dairy, and pork. One of the leaders in the supply of minerals to China is Australia, for which it is the main exporting country. These are various ores, including iron and copper. Australia is also the largest supplier of liquefied natural gas to China with a $44 \%$ share (Khotimsky, 2019). China is also the main importer of Brazilian products, importing soybean flour, crude oil and iron ore concentrate (Brazil's foreign trade turnover, 2019). Obviously, China aims to gain the status of a core country in international trade.

However, according to a number of indicators, especially in the socio-economic field, China cannot be attributed to the core countries, from which the hegemon of the world system usually rises. First of all, it is an indicator of GDP per capita (see Table 1). The per capita GDP of China is still less than the world average by 
$\$ 1,168$, which does not allow ranking it among developed countries, and is 6 times lower than that of the US. The Human Development Index, which combines information on people's health, education and income in one indicator, does not correspond to a group of countries with a very high development level. The degree of income inequality in China is too high for the level of developed core countries. So, according to Table 1, the Gini coefficient in China is 51.0, and in the USA it is 37.8.

Accordingly, the PRC is not yet able to demonstrate the most attractive lifestyle for the world's population (especially for the most developed countries), which is necessary for a hegemon. China now more likely has the status of a strong semi-periphery, making a centripetal movement, and preparing for the role of the new capitalist accumulation regime leader. However, the results of the applicant's competition with the current world-system hegemon are not yet obvious.

According to the world-system analysis approach, this means: firstly, the formation of systemic advantages in the sphere of production and trade, finance and military power in order to derive the maximum possible amount of world-system rent from the functioning of the world economy, and secondly, ensuring sufficiently powerful positions in the interstate system, which also increases the amount of appropriation of world-system rent. These activities have a synergistic effect, i.e. the achievements in one activity increase the position of the actor in another activity. This is a long process with a number of stages, and the state is implementing a long-term project to guide this process. China maintains its course, demonstrating the presence of not just strategic thinking, but long-term strategic thinking and planning, calculated until 2049 (The Main Trends, 2019).

The PRC gradually creates the conditions for the world-system of economic leadership required by a hegemon, while continuing to assert itself as a developing country. First of all, China faces the typical task of trade leaders to reduce transport costs and improve transportation security. To draw more world-system rent from international trade, it is necessary to create an efficient and controlled infrastructure for the delivery of goods. To this end, China is actively building the architecture of new trade routes. The basis of such a system is the implementation of the "Belt and Road Initiative" (Huang, 2016), which combines the "Silk Road Economic Belt" and the "21st Century Maritime Silk Road" projects launched in September, 2013. China is implementing innovations in comparison with the global trade logistics in previous systemic cycles of capital accumulation in the world economic system. In contrast to the dominance of the system of maritime trade routes in the previous cycles, the PRC assigns the main role to land rail and road trade routes. The PRC is actively entering Europe. More than 170 cooperation documents have already been signed with 150 international entities, including developing and developed countries, i.e. Italy and Luxembourg (Pirozhenko, 2019).

China is strengthening its position in the field of military power and arms production, actively cooperating not only with the Russian Federation, but also with leading EU countries. According to the Stockholm International Peace Research Institute (SIPRI), the PRC ranks second among the world's largest military spending countries after the United States. Its military budget in 2018 is \$ 250 billion, which is $1.9 \%$ of GDP. China's military spending is rising for the 24th consecutive year. In 2018, they were almost 10 times higher than in 1994. US military spending is $\$ 649$ billion. These two countries account for almost half of the world's military spending, and the increase in world military spending is connected precisely with the increase in spending in these countries (SIPRI, 2019).

The increase in military spending in China is associated with the announced reform of the national defense and armed forces. Its goal is to increase the percentage of military equipment and weapons of Chinese manufacture and the introduction of modern technology. However, in general, Beijing's military capabilities, according to experts, are still significantly inferior to the resources available to the United States, especially in the field of nuclear weapons (China's military budget, 2019). The Chinese signed a contract with French and FrancoGerman companies to jointly conduct research on creating a promising fighter development program (Vavilov and Peretolchin, 2019). 


\section{Prospects for Changing Relations in the World Economy in the Case if the PRC Leadership Comes True}

What kind of economic relations is China trying to establish in the world? In production, it seeks to obtain a world-system rent through specialization in more complex and profitable product creation operations, transferring simple assembly and packaging links in the production chain to the neighboring countries. At the same time, it uses the channel for obtaining world-system rent by organizing production using cheap resources of the capital recipient countries. Such resources, in particular, include bauxite, copper, nickel, beryllium, titanium and rare earth elements. Already in 2017, China took first place in providing loans to African countries, the total volume of which exceeded the 2010 level by 50 times. In the field of direct and portfolio investments, the main partners of China are Egypt, Nigeria, Algeria, South Africa, Ethiopia, DRC, Zambia, Angola, Morocco, Niger, Cameroon, Chad and some other countries. It is known that many African countries have a geographically favorable position, cheap labor and good conditions for trade. Investment policy is implemented with the help of powerful investment funds created with the participation of state capital, for example, the China-Africa Development Fund, created on the basis of the authorized capital provided by the State Development Bank of China in 2007 (Belyaev and Makarova, 2018). China and France signed agreements on the development of Africa. Since 2009, China has been the main partner of African countries in the field of trade and investment (Chen, Dollar, Tang, 2018).

At the same time, China uses a model of the "debt trap" in the economic development and financing of projects in developing countries in exchange for their natural resources and access to markets. Chinese state-owned companies are building facilities in developing countries, increasing their debt dependence, and then, taking into account the repayment, they take control over a particular infrastructure or raw material resource. This is especially efficient for countries characterized by weak legal systems and authoritarian regimes. For example, as a result of China-Africa fund project, the Chinese company Sinochem International acquired 24 rubber plantations on the territory of 150 thousand hectares and plants in Cameroon, Cote d'Ivoire, DRC (Kinshasa), Nigeria, Ghana and Gabon (Belyaev and Makarova, 2018).

Something like proletarian internationalism can be hardly supposed in the actions of modern China. The "Chinese world" sees its civilization in relations with the rest countries, primarily with the Indo-European, IndoAryan world, as "global competition". The famous sinologist N. Vavilov notes: "The very definition of China as Chung-go, "the middle state", contrasts it with everyone else, an external alien world (Wai). Wai guo are foreign countries, an alien world, unpleasant to the Chinese. The goal of China is to accumulate all the technologies in itself, to spin the whole world around itself" (Vavilov and Peretolchin, 2019).

Since the 80 s of the last century, China, by the will of its ruling class, has integrated into the capitalist worldsystem. This integration model was later designated as the Beijing Consensus, a concept introduced by British economist Joshua Ramo in 2004. According to him, the sense of this category is contrasting the Chinese development model denoted by the Washington Consensus category. The concept of the Washington Consensus was introduced in November 1989 by the American economist John Williamson and includes the sum of the World Bank recommendations on how to overcome the economic crisis in Latin America. They were used as strategies for the transition of countries with an administrative-command economy to the capitalist system.

J. Ramo noted: "By "Beijing consensus" I meant the consensus of nations. Brazil, Russia, India and China are all examples of such consensus. This consensus is that the Washington model is not the only possible one" (Ramo, 2010). It should be emphasized that for all the differences in the paths of economic development described by Beijing and Washington consensus models, they have a very important commonality - both of them are the ways of integration into the capitalist world-system. Theoretically, the world-system is a category that is immeasurably more substantial than the Washington Consensus and the Beijing Consensus, which describe only certain options for the functioning of specific economies in the conditions of the beginning of the $21 \mathrm{st}$ century of the existence of the world-system. The Chinese social and economic system is not specific Chinese socialism and is Asian state capitalism. 
Currently, there are serious risks for the successful development of China, including the rapid growth of debts in the Chinese economy. According to the McKinsey advisory company, China overtook the United States in terms of relative total debt: in America it amounted to $269 \%$ of GDP and in China - 282\%, according to which, as company analysts argue, China can cause threat to economic and financial stability.

\section{Conclusions}

The study of the economic description of the PRC does not confirm the opinion that a special model of socialism with Chinese characteristics is being implemented in this state. The model of China is not specific socialism. Rather, at this time it is specific capitalism, that is, capitalism, in which a special mode of capital accumulation is formed - with a higher role of the state in the process of capital accumulation than in the fourth cycle of capital accumulation.

Trends in the Chinese state-economic system in the 21 st century suggest that this is the authoritarian capitalism. The country is steadily increasing the power and technological level of the economy in all aspects, including military potential. To spread Chinese values and augment the appropriated world-system rent, China, along with intensifying its economic influence within the existing world-system, uses new, China-oriented tools, such as the "Belt and Road Initiative" and powerful investment funds created with the participation of state capital, including the China-Africa Development Fund, etc.

China is carrying out a systematic process of "passing hurdles" on the path to economic leadership, but if its path leads it to the goal, this will be the first time a specific non-Western leadership.

\section{References:}

Arrighi, G. (2010). The Long Twentieth Century: Money, Power, and the Origins of our Time, Verso, London.

Belyaev, S., Makarova, I. (2018). Chinese Investment in Africa: China-Africa Development Fund Practices. Retrieved March 29, 2020, from https://russiancouncil.ru/analytics-and-comments/columns/africa/kitayskie-investitsii-v-afrike-praktika-fonda-razvitiya-kitayafrika/ (In Russian).

Brazil's foreign trade turnover in 2018 reached its highest level in the last 5 years (2019). Retrieved March 29, 2020, from https:// finance.rambler.ru/markets/41517962-oborot-vneshney-torgovli-brazilii-v-2018-godu-dostig-naivysshego-urovnya-za-poslednie5-let/?utm_source=copylink\&utm_medium=read_more\&utm_content=finance_media (In Russian).

Chen, W., Dollar, D., Tang, H. (2018). Why is China investing in Africa? Evidence from the firm level. World Bank Economic Review, 32(3), 610-632.

China. Data and statistics (2020). Retrieved March 29, 2020, from https://knoema.ru/atlas/Китай (In Russian).

China. Export (2019). Retrieved March 29, 2020, from https://trendeconomy.ru/data/total_structure_h2?time_period=2018\&reporter= China\&trade_flow=Export\&commodity=TOTAL\&partner=World (In Russian).

China. Import (2019). Retrieved March 29, 2020, from https://trendeconomy.ru/data/total_structure_h2?time_period=2018\&reporter= China\&trade_flow=Import\&commodity=TOTAL\&partner=World (In Russian).

China. Import and export (2020). Retrieved March 29, 2020, from https://trendeconomy.ru/data/h2?time_period=2015,2016,2017,201 $8 \&$ reporter=China (In Russian).

China's foreign trade in 2018 rose to an all-time high \$ 4.6 trillion (2019). Retrieved March 29, 2020, from https://www.interfax.ru/ business/645971 (In Russian).

China's military budget has exceeded the Russian several times: much inferior to the United States (2019). Retrieved March 29, 2020, from https://www.mk.ru/politics/2019/03/05/voennyy-byudzhet-kitaya-v-razy-prevysil-rossiyskiy-do-ssha-daleko.html (In Russian).

Colas, M., Ge, S. (2019). Transformations in China's Internal Labor Migration and Hukou System. Journal of Labor Research, 40(3), 296-331.

Deng Xiaoping and His Economic Reforms (2016). Retrieved March 29, 2020, from https://fb.ru/article/264312/den-syaopin-i-ego- 
ekonomicheskie-reformyi (In Russian).

Estachy, L. (2015). Geopolitics and Global Capital markets: US - China relations since the 80s. Izvestiya of Irkutsk State Economics Academy, 25(4), 677-690 (In Russian).

Glaziev, S.Yu. (2016). National Economy Structures in the Global Economic Development. Economics and Mathematical Methods, 52(2), 3-29. (In Russian).

Global GDP of the World: 1980-2018 (2019). Retrieved March 29, 2020, from http:/global-finances.ru/vvp-mira-po-godam/ (In Russian).

Global Innovation Index 2018. Energizing the World with Innovation (2018). Retrieved March 29, 2020, from https://www.wipo.int/ publications/en/details.jsp?id=4330

Huang, Y. (2016). Understanding China's Belt \& Road Initiative: Motivation, framework and assessment. China Economic Review, 40, 314-321.

Human Development Indices and Indicators. 2018 Statistical Update (2018). Retrieved March 29, 2020, from http://hdr.undp.org/sites/ default/files/2018_human_development_statistical_update.pdf

Khotimsky, K.V. (2019). The current state of gas imports to China in 2014-2018 and the prospects for Russian gas in the Chinese gas market. Retrieved March 29, 2020, from https://www.imemo.ru/files/File/ru/conf/2019/05042019/10-HOTIMSKY-PRZ.pdf (In Russian).

Kononovich, E. (2017). China Reduces State Share in Economy. Retrieved March 29, 2020, from https://www.sb.by/articles/bogatymine-rozhdayutsya.html (In Russian).

Liu, Ya, Chernetsova, N.S. The main indicators of China's foreign trade: analysis of current trends (2018). Bulletin of Penza State University, 4, 40-46.

Lukin, A.V. (2011). On Some Problems of Comparative Studies of the Political Systems of the PRC and the USSR. Comparative politics, 2(1), 3-18 (In Russian).

Mussapirov, K., Djalkibaev, J., Kurenkeyeva, G., Kadirbergenova, A., Petrova, M., Zhakypbek, L. 2019. Business scaling through outsourcing and networking: selected case studies, Entrepreneurship and Sustainability Issues, 7(2), 1480-1495. http://doi.org/10.9770/ jesi.2019.7.2(48)

Naama, K. 2001. „International Movement of Foreign Direct Investments,” Economic Thought journal, Bulgarian Academy of Sciences - Economic Research Institute, 5: 81-92. https:/www.ceeol.com/search/article-detail?id=221618

Naama, K. 2011. Problems and Solutions for Establishing the Private Sector in Developing Countries. Economic Archive. D. A.Tsenov Academy of Economics- Svishtov. ISSN: 0323-9004, eISSN: 2367-9301, 1: 28-41 https://www.ceeol.com/search/article-detail?id=168228

Nuruzzaman, M. (2016). China's rise, the USA and global order: Contested perspectives and an alternative approach. International Area Studies Review, 19(2), 177-194.

Pirozhenko, V. (2019). Chinese "Belt and Road" Cover the Old World. Retrieved March 29, 2020, from https://www.fondsk.ru/ news/2019/05/01/kitajskie-pojas-i-put-ohvatyvajut-staryj-svet-48108.html (In Russian).

Pye, L.W. (1992). The Spirit of Chinese Politics, Harvard University Press, Cambridge.

Ramo, J.C. (2010). "Beijing Consensus as the Consent of Nations". Retrieved March 29, 2020, from http://www.intelros.ru/pdf/Rus Jornal/49/10.pdf (In Russian).

Semin, A.V. (2011). China: Rapid Development of the Private Sector of the Economy. Retrieved March 29, 2020, from http://www.ifesras.ru/publications/21-press/327-semin-av-qkitaj-bystroe-razvitie-negosudarstvennogo-sektora-ekonomikiq (In Russian).

Shuvalov, N. (2020). Industries of the World's Countries. Retrieved March 29, 2020, from https://visasam.ru/emigration/economy/ promyshlennost-stran-mira.html (In Russian).

SIPRI: top 10 countries with the highest military spending in 2018 (2019). Retrieved March 29, 2020, from https://www.vesti.ru/doc. html?id=3142680\&cid=6 (In Russian).

Sun, X. (2019). USA, China and Global Leadership: Analysis in the Perspective of Conceptualisation. India Quarterly, 75(2), $190-205$. 
The Leading Nations in World Trade (2018). Retrieved March 29, 2020, from https://credinform.ru/ru-RU/Publications/ Article/70c051c725f5 (In Russian).

The Main Trends. Round Table at Izborsk Club (2019), ZAVTRA, 27 February, pp. 1-3 (In Russian).

The Position of the Working Class in China. Faces of Migration (2010). Retrieved March 29, 2020, from https://aitrus.info/node/677 (In Russian).

Tvaronavičienè, M. (2019). Insights into global trends of capital flows' peculiarities: emerging leadership of China. Administratie si Management Public, 32, 6-17. DOI: 10.24818/amp/2019.32-01.

United Nations, Department of Economic and Social Affairs, Population Division (2019). World Population Prospects 2019, Online Edition. Retrieved March 29, 2020, from https://population.un.org/wpp/Download/Standard/Population/

Vavilov, N., Peretolchin, D. (2019). Hidden Dragon. About the Myths and Realities of China, ZAVTRA, 7 August, p. 3-4 (In Russian).

Wallerstein, I. (1999). The End of the World as We Know it: Social Science for the Twenty-first Century, University of Minnesota Press, Minneapolis.

World Economies Ranking 2019, Table of World GDP (2019). Retrieved March 29, 2020, from https://basetop.ru/rejting-ekonomikmira-2019-tablitsa-vvp-stran-mira/ (In Russian).

World Economy Review - September 2019 (2019). Retrieved March 29, 2020, from http://www.ereport.ru/reviews/rev201909.htm (In Russian).

Short biographical note about the contributors at the end of the article (name, surname, academic title and scientific degree, duties, research interests):

Natalya V. OSOKINA, Professor, Dr. Sci. (Economic), T.F. Gorbachev Kuzbass State Technical University, Institute of Economics and Management, Professor of Department of Economics (Kemerovo, Russian Federation). Professional interests: world-system analysis. ORCID ID: https://orcid.org/0000-0001-8346-9848

Mariana PETROVA, Professor, D.Sc in Physics and Mathematics, Assoc. Prof. St. Cyril and St. Methodius University of Veliko Tarnovo, Bulgaria; Professor Economics and Management in Department of Management, ISMA University, Riga, Latvia. Research interests: management of IT processes, smart data analysis in economics, systems information security.

ORCID ID: https://orcid.org/0000-0003-1531-4312

Natalia V. KUDREVATYKH, Associate Professor, Cand. Sci. (Economic), T.F. Gorbachev Kuzbass State Technical University, Director of Institute of Economics and Management, Associate Professor of Department of Finance and Credit. Professional interests: economic security.

ORCID ID: https://orcid.org/0000-0003-3132-6444

Evgeny E. ZHERNOV, Associate Professor, Cand. Sci. (Economic), T.F. Gorbachev Kuzbass State Technical University, Institute of Economics and Management, Head of Department of Economics (Kemerovo, Russian Federation). Professional interests: anthroposocial global issues.

This work is licensed under the Creative Commons Attribution International License (CC BY). http://creativecommons.org/licenses/by/4.0/ 